\title{
A PROPÓSITO DE MOMO E CORPO CARNAVALESCO: DE JOAN BAVECA E A SÁTIRA GALEGO-PORTUGUESA AO CANCIONEIRO GERAL*
}

\author{
MARIA ISABEL MORÁn CABANAS \\ Universidade de Santiago de Compostela \\ ORCID iD: https://orcid.org/0000-0002-8343-7325
}

* O presente estudo vincula-se às investigações levadas a cabo no marco dos projetos Paleografía,
lingüística y filología. Laboratorio on-line de la lírica gallego-portuguesa (FFI 2015-68451-P),
subsidiado pelo Ministerio de Economía y Competitividad e pelos FEDER, e Voces, espacios y re-
presentaciones femeninas en la lírica gallego-portuguesa (PID 2019-108910GB-C22), subsidiado
pelo Ministerio de Ciencia e Innovación.

Copyright: (C) 2021 CSIC. La edición electrónica de esta revista se distribuye bajo los términos de una licencia de uso y distribución Creative Commons Reconocimiento 4.0 Internacional (CC BY 4.0).

Cómo citar/Citation: Maria Isabel MoRÁn CABANAS, "A propósito de momo e corpo carnavalesco: de Joan Baveca e a sátira galego-portuguesa ao Cancioneiro Geral", Cuadernos de Estudios Gallegos, 68, núm. 134 (2021), págs. 125-156, https://doi.org/10.3989/ceg.2021.134.04 


\title{
A PROPÓSITO DE MOMO E CORPO CARNAVALESCO: DE JOAN BAVECA E A SÁTIRA GALEGO-PORTUGUESA AO CANCIONEIRO GERAL
}

\section{RESUMO}

Numa cantiga de Joan Baveca a Pero d'Ambroa -ambos integrados no "cancioneiro de jograis galegos"- regista-se a única ocorrência de momo no corpus trovadoresco galego-português. Até hoje, tal pormenor não tem sido objeto de atenção dos investigadores, que se limitaram praticamente a reiterar a indicação de Rodrigues Lapa sobre o seu valor num registo coloquial e em sentido figurado na edição de Cantigas d'escarnho e de mal dizer (1965). O nosso objetivo é refletir acerca de tal vocábulo através de várias vias: 1. análise de hipóteses sobre a sua origem; 2. revisão de documentação coetânea às cantigas e de textos literários posteriores, sobretudo os do Cancioneiro Geral que aludem aos momos cortesãos; 3. cotejo de expressões que ligam riso e corpo sob o prisma da carnavalização. Assim, certas isotopias literárias ao serviço do humor, a história da (pré) teatralidade e a proposta de uma nova entrada no repertório lexicográfico galego-português são os pontos nucleares do presente estudo.

PalaVRas chaVE: momo, carnavalização, Joan Baveca, Pero d'Ambroa, Garcia de Resende, (pré) teatralidade

\section{A PROPÓSITO DE MOMO Y CUERPO CARNAVALESCO: DE JOAN BAVECA Y LA SÁTIRA GALLEGO-PORTUGUESA AL CANCIONEIRO GERAL}

\section{RESUMEN}

En una cantiga de Joan Baveca a Pero d'Ambroa -ambos integrados en el "cancioneiro de jograis galegos"- se registra la única ocurrencia de momo en el corpus trovadoresco gallego-portugués. Hasta hoy, tal detalle no ha sido objeto de atención de los investigadores, que se limitaron prácticamente a reiterar la indicación de Rodrigues Lapa sobre su valor en un registro coloquial y en sentido figurado en su edición de Cantigas d'escarnho e de mal dizer (1965). Nuestro objetivo es formular una serie de reflexiones acerca de tal vocablo por varias vías: 1 . análisis de hipóteses sobre su origen; 2. revisión de documentación coetánea a las cantigas y de textos literarios posteriores, concretamente los del Cancioneiro Geral que aluden a la representación de momos cortesanos; 3. cotejo de expresiones que vinculan risa y cuerpo bajo el prisma de la carnavalización. Así, ciertas isotopías literarias al servicio del humor, la historia de la (pre)teatralidad y la propuesta de una nueva entrada en el repertorio lexicográfico gallego-portugués son puntos nucleares de nuestro estudio. PALABRAS ClAVE: momo, carnavalización, Joan Baveca, Pero d'Ambroa, Garcia de Resende, (pre) teatralidad.

\section{SOME REFLECTIONS ON MOMO AND THE CARNIVALESQUE BODY: FROM JOAN DE BAVECA AND THE GALICIAN-PORTUGUESE SATIRE TO THE CANCIONEIRO GERAL}

\begin{abstract}
In a song by Joan Baveca addressed to Pero d' Ambroa -both included in the "songbook of Galician jongleurs"- we find the only occurrence of the word momo in the corpus of Galician-Portuguese troubadour lyric. To date, this detail has been overlooked by scholars, who practically limited themselves to reiterating the theory put forward by Rodrigues Lapa with regard to its value in a colloquial register and in a figurative meaning, in his edition of Cantigas d'escarnho e de mal dizer (1965). Our aim is to reflect on this word, by means of several paths: 1. an analysis of hypotheses as to its origin; 2. a review of documents and literary texts contemporary to the songs, especially those in the Cancioneiro Geral that mention the representation of courtly momos; 3. a comparison of expressions linking laughter and body from the carnivalesque perspective. Therefore, certain humorous literary isotopies, the history of pre-theatricality and the proposal of a new entry in the Galician-Portuguese lexicographic repertoire are all pivotal points in our study.

KeY words: momo, Carnival, Joan Baveca, Pero d'Ambroa, Garcia de Resende, pre-theatricality.
\end{abstract}


Recibido/Received: 14/02/2020

Aceptado/Accepted: 20/09/2020

Ele [o corpo carnavalesco] caracteriza-se, principalmente, pela lógica original das coisas "ao avesso", "ao contrário", das permutações constantes do alto e do baixo... e pelas diversas formas de paródia, travestis, degradações, profanações, coroamentos e destronamentos bufões.

Mikhail Bakhtin

U ma das trinta cantigas que fazem parte do corpus conservado de Joan Baveca contém a única recorrência do vocábulo momo na lírica galego-portuguesa (B 1457, V 1067). Trata-se de uma composição de escárnio e maldizer que aparece endereçada a Pero d'Ambroa, com quem o autor também estabelece uma relação direta noutro texto que temos de lembrar igualmente aqui a fim de penetrar num espaço poético dentro do qual os termos ganham significações particulares e se amoldam ao serviço da sátira. Embora de forma breve, devemos aproximar-nos, ainda, de algumas disputas verbais em que um ou outro jogral galego participa, assim como das mofas dirigidas ao segundo e da presença dos motivos que inspiram reiteradamente estas ao longo da produção escarninha, atentando ora em coincidências ora em divergências léxico-semânticas, discursivas e intencionais. Cabe considerar, com efeito, que uma revisão de tais textos, num determinado entorno de convívio social e literário, contribuirá para facilitar a interpretação do vocábulo em questão, refletir sobre as suas possibilidades de uso e desentranhar tanto os seus valores, como os das expressões adjacentes, no âmbito em que se inscrevem e na sua projeção a través de tempos e espaços.

\section{JoAn Baveca e Pero D'Ambroa: ReFERÊnCIAs teXtuais}

As poucas informações de que dispomos sobre Joan Baveca ligam-se, por um lado, à posição que a sua produção ocupa nos cancioneiros, aparecendo incluída no grupo de jograis galegos; por outro, às alusões que nos seus versos remetem para o contacto com figuras coetâneas do espetáculo trovadoresco (quer dizer, 
Pero d'Ambroa, Pedr' Amigo de Sevilha, Bernal de Bonaval ou a soldadeira Maria Balteira), as quais permitem situá-lo cronologicamente no segundo terço do século XIII, nas cortes de Fernando III e Afonso X ${ }^{1}$. Quanto ao Pero d'Ambroa citado na sua cantiga, não se possui certeza do seu parentesco com Pero Garcia d'Ambroa -referência onomástica que também aparece na tradição manuscri$\mathrm{ta}^{2}-$, mas cabe pensar na hipótese de ter pertencido a uma camada secundária da mesma linhagem, o que poderá confirmar a consideração dele como jogral, conforme se infere da sua inclusão no "cancioneiro de jograis galegos". Segundo a documentação, cabe pensar que o desenvolvimento da sua atividade literária teria lugar no marco cronológico que vai de 1235 a $1255^{3}$.

Numa das mais longas tenções que foram conservadas na tradição manuscrita, Joan Baveca debate com Pedr'Amigo de Sevilha (B 1221, V 826) acerca do estado que supõe uma maior grau de insensatez (qual destes ambos é de peior sén $\left.{ }^{4}\right)$ : o do homem de baixa condição social que ama uma dama de mais alta linhagem, mas da qual não cabe esperar nenhum bem, ou o do que serve uma mulher de categoria inferior, mas condescendente? O primeiro fala do ponto de vista do vilão -porventura em consonância com o seu status-, defendendo este como indivíduo que não age por interesse, enquanto o seu interlocutor se situa na posição de alguém convencido do seu valor, recorrendo ao duplo sentido de bon como qualidade social e ético-moral. Aliás, é esse mesmo trovador que, numa célebre cantiga satírica (B 1664, V 1198), manifesta o seu ceticismo quanto à

\footnotetext{
${ }^{1}$ Lembre-se, porém, que o Nobiliário do Conde D. Pedro regista tanto o nome de um Fernão Baveca, casado, em segundas núpcias, com D. Teresa Peres de Vide, como o dos seus filhos, Fernão e Afonso Baveca (veja-se António Resende de Oliveira, Depois do espectáculo trovadoresco. A estrutura dos cancioneiros peninsulares e as recolhas dos séculos XIII e XIV, Lisboa, Colibri, 1994, pág. 358). A sua esposa, sobrinha do trovador Fernan Fernandez Cogominho, talvez seja a mulher de que fala como objeto do seu amor e sofrimento numa composição da sua autoria: a mia sobrinha mi tolheu / o sén, por que ando sandeu (B 366). Aliás, a documentação localiza também esse Fernão Baveca em terras de Barroso, no norte de Portugal, na segunda metade de Duzentos. Embora não pareça completamente impossível que o poeta Joan Baveca pertença à mesma estirpe e que a sua identidade se corresponda, portanto, com a de um cavaleiro português, não existem dados que venham alicerçar tal hipótese.

2 Perante o registo desses nomes parcialmente coincidentes, os investigadores têm-se empenhado em descobrir se estamos perante um ou dois indivíduos. Face da tese tradicional que se inclinava a favor da identificação numa só pessoa, nas últimas décadas tende-se a defender a opinião contrária, pois "se Pero Garcia de Ambroa já estava morto em 1233, e se Pero de Ambroa tem composições que devem ser datadas com posterioridade, é forçoso concluir que são duas pessoas distintas" (Yara FratesCHI VIEIRA, En cas dona Maior. Os trovadores e a corte señorial galega no século XIII, Laiovento, Santiago, 1999, pág 114). Para uma revisão das diversas tentativas de reconstrução do perfil biográfico de ambas as figuras, veja-se o artigo de José António Souto CABO, "Pedro Garcia de Ambroa e Pedro de Ambroa", Revista de Literatura Medieval, 18 (2006), págs. 225-248.

3 Souto CABO, "Pedro Garcia de Ambroa...", pág. 236.

${ }^{4}$ Para a transcrição dos versos das cantigas trovadorescas ao longo do artigo, seguimos as normas estabelecidas em Manuel Ferreiro, Carlos Paulo Martínez Pereiro e Laura TAto Fontaíña, Normas de edición para a poesia trovadoresca galego-portuguesa medieval. Guidelines for the Edition of Medieval Galician-Portuguese Troubadour Poetry, A Coruña, Servizo de Publicacións, 2007.
} 
A PROPÓSITO DE MOMO E CORPO CARNAVALESCO:

capacidade de Joan Baveca e do seu congénere Pero d'Ambroa para compor, no desempenho do seu exercício profissional como jograis, uma tenção com resultados satisfatórios: os dois já tentaram, desistiram e voltaram a começar, mas nunca com êxito. Em palavras de Pedr'Amigo de Sevilha, que aproveita a ocasião para aludir a uma presumível e muito ridiculizada peregrinação de Pero d'Ambroa pelos seus coetâneos às terras de Jerusalém: Joan Baveca e Pero d'Ambrõa / começaron de fazer sa tençon / e sairom-se logo da razon.

Porém, apesar de tal declaração jocosa sobre essa falta de dotes para a prática do género poético mencionado -ou mesmo à maneira de réplica-, os dois visados conseguem concluir um debate cujo assunto gira à volta da sinceridade dos cantares que Joan Baveca interpreta, a sua estrutura métrica e a sua execução (B 1573) $)^{5}$. Aliás, não podemos esquecer que este se situa na linha de diversos poetas frequentadores do mesmo círculo cultural que manifestam a sua falta de credibilidade a propósito dos deslocamentos devocionais de Pero d'Ambroa que acima referimos. Nesse sentido, compõe uma cantiga (B 1456, V 1066) em que se mofa da sua alegada visita ao famoso santuário de Santa Maria de Rocamadour, no sul da França: se noutra viagem (a da Terra Santa) teria ido apenas a Montpellier, nesta tão só chegaria ao alto dos Pirenéus e daí voltaria para trás. Nos versos alude-se, de facto, ao Monte Roldão (poio de Roldan), menção que parece inspirada na Chanson de Rolland, com vista a pôr em destaque o "heroísmo" do protagonista 6 :

\section{Pero d'Ambroa prometeu de pran que fosse romeu de Santa Maria, e acabou assi sa romaria com'acabou a do frume Jordan:}

\footnotetext{
5 Joan Baveca nega-se a interpretar a obra de Pero d'Ambroa, alegando que ele só se ocupa dos verdadeiramente sentidos e compostos nas medidas certas (veja-se Carlos Alvar, "Las poesías de Pero Garcia d'Ambroa", Studi Mediolatini e Volgari, 32 (1986), pág. 44). A crítica parece deslocar-se, então, para algum trovador a que Joan Baveca prestaria serviço, afirmando que esse conhece tanto a coita de amor como sab'o asno de ler, ataque a que o jogral contesta com veemência. Assim sendo, poderíamos dizer que estaríamos perante um exercício raro nas cantigas galego-portuguesas: o da dupla defesa (confrontese Graça Videira Lopes (ed.), Cantigas medievais galego-portuguesas [base de dados online], Lisboa, Instituto de Estudos Medievais, FCSH/NOVA, 2011, disponível em < https://cantigas.fcsh.unl.pt/apresentacao.asp > [Consulta 22/12/2019]).

${ }^{6}$ No corpus lírico galego-português apenas conservamos, para além dessa cantiga, uma outra em que se recorre à célebre obra épica para parodiar, de modo bastante mais mordaz, o comportamento anticavaleiresco, Sedia-xi Don Belpelho en ũa sa maison (B 1470, V 1080), de Afonso Lopez de Baian. Tanto num como noutro caso a referência é tão geral que se torna difícil tirar conclusões definitivas acerca dos textos em circulação sobre tal canção de gesta na parte centro-ocidental da Península, como explica Pilar LOREnZo Gradín no estudo "Modelos épicos y artúricos en la lírica gallego-portuguesa", em Marco Piccat e Laura Ramello (coords.), Epica e cavalleria nel Medioevo, Atti del Seminario Internazionale, Alessandria, Edizioni dell’Orso, 2011, pág. 78).
} 
ca entonce atá Mompilier chegou
e ora per Roçavales passou
e tornou-se do poio de Roldan.

Embora as lacunas dos cancioneiros não nos permitam conhecer na íntegra o conteúdo da última cobra, parece possível deduzir que o jogral poria na boca do peregrino a reflexão sobre a procura de uma prova inexorável para fingir a viagem, a qual encontrou no corno de marfim ou olifante com que foi armado Roldão, comandante dos francos e sobrinho de Carlos Magno (e ach'aqui o corno de Roldan).

Também de forma incompleta nos chegou a composição que se conserva a continuação dessa na tradição manuscrita, onde nos deparamos precisamente com o vocábulo momo (B 1457, V 1067) ${ }^{7}$. Na verdade, as suas cobras segunda e terceira resultam ilegíveis quer no Cancioneiro da Biblioteca Nacional quer no da Vaticana:

Pero d'Ambroa, sodes maiordomo

e trabalhar-s'-á de vos enganar

o albergueiro; mais d'escarmentar-

lo havedes, e direi-vos eu como:

se vos mentir do que vosco poser

seja de vós e de nós, como quer,

e brita[de]-lh'os narizes no momo.

A de nosso...

...

$\cdots$

$\cdots$

$\cdots$

$\cdots$

E...

$\cdots$

$\cdots$

$\cdots$

\footnotetext{
${ }^{7}$ As rimas com maiordomo e como apontam, sem dúvida alguma, para o termo em questão, mas cabe assinalar, no entanto, que a lição em ambos os códices italianos é "mamo".
} 
A PROPÓSITO DE MOMO E CORPO CARNAVALESCO

E pois mercade-lo al, logo cedo vo[s] amostr'a roupa que vos dara e, se pois virdes que vo-la non dá ide sarrar-la port', a vosso quedo e desses vossos narizes $\log ^{\prime} i$ fic'o seu cuu quebrantad'assi que ja sempre aja d'espanhoes medo.

Tendo em conta os versos em que se inscreve a palavra, assim como alguns textos que acima foram já comentados e outros com que parecem dialogar direta ou indiretamente, cabe pensar que a cantiga transcrita foi também redigida a partir de alguma viagem (ou presumível viagem) de Pero d'Ambroa a terras de além Pirenéus. Embora não seja fácil discernir o sentido do texto, parece que ali Joan Baveca aconselha o seu congénere, a fim de prevenir que se torne vítima de engano por parte de um albergueiro durante o desempenho das suas funções como mordomo - de quem? nem se revela nem se sugere a identidade de tal personagem, mas torna-se lógico pensar que se trata de algum grande senhor. Caso o estalajadeiro não cumpra o combinado na negociação prévia, a recomendação proposta é dar-lhe um forte escarmento: aplicar-lhe o nariz no momo (e brita[de]-lh'os narizes no momo).

\section{REFLEXÕES SOBRE A ORIGEM E O SIGNIFICADO CONTEXTUAL DE MOMO NA SÁTIRA GALEGO-PORTUGUESA}

$\mathrm{Na}$ cantiga acima transcrita regista-se a única ocorrência do vocábulo sublinhado em todo o corpus da lírica galego-portuguesa, acerca do qual M. Rodrigues Lapa e os editores posteriores indicam, a modo de hipótese (veja-se o uso do modo condicional com valor de probabilidade), e sem mais explicações ou justificações, um significado que cabe adivinhar, efetivamente, pelo contexto: "seria uma curiosa expressão de gíria com o sentido de traseiro" momo aparece situada em posição de rima com mordomo e como na cobra inicial, na quarta e última substitui-se por cu: e desses vossos narizes $\log ^{\prime} i$ / fic'o seu cuu quebrantad'assi. Mas, na verdade, não o encontramos registado em nenhum outro texto medieval, seja do género que for, com esse valor semântico de zona inferior e posterior do dorso. Quanto ao conteúdo da cantiga, Joan Baveca

\footnotetext{
${ }^{8}$ Manuel Rodrigues Lapa (ed.), Cantigas d'escarnho e de mal dizer, Vigo, Galaxia, 1965, pág 294.
} 
mantém até ao final a insistência na sugestão de mostrar a mesma reação como revanche perante um possível engano: convém que Pero d'Ambroa ajuste tudo com o hospedeiro antes e, se vir que este não dá a roupa acertada, ele fechará a porta lenta e sigilosamente e quebrantar-lhe-á o traseiro com o seu nariz. E fá-lo-á com tanto empenho que o atacado deverá ficar para sempre com temor dos espanhoes (que sempre ache d'espanhoes medo), cobrindo-se assim os versos, ironicamente, de um tom modelar ou exemplar. Dada a origem galega de Pero d'Ambroa, podemos pensar que esse gentílico possui o sentido geral de habitantes da Península Ibérica ou Hispânia, aqui em contraposição às terras de além Pirenéus, onde se situaria a cena entre o jogral-mordomo e o albergueiro.

Sob uma mundividência carnavalesca que se alicerça na percepção grotesca do corpo e das suas partes baixas, parece lícito remeter para a popularidade, no universo dos mitos gregos, de uma divindade tão periférica como a do Momo, convertido literariamente num estereótipo burlesco. Tal como aconteceu com Baco, tornou-se um referente habitual para momentos de mofa e humor e funcionou mesmo como a personificação do sarcasmo em obras dos mais diversos géneros e épocas ${ }^{9}$. Representava-se precisamente com uma máscara que levantava para que se lhe visse o rosto e por meio de um boneco ou um cetro com uma cabeça grotesca na mão como símbolo da loucura. Nas celebrações do Carnaval transformou-se, de facto, num rei que costuma visualizar-se num homem corpulento e bochechudo, agente e dirigente de manifestações marcadas pela desinibição e o desenfreamento. Vale a pena revisitar, com efeito, a definição que da palavra em foco fornece Rafael Bluteau a propósito da sua relação com a mitologia e das aceções daí derivadas e relativas à máscara:

Poderia derivarse de Momus, filho da noite, \& do sono, \& na antiga gentilidade, fabuloso deos da censura maliciosa, \& critica ridicula. Diz a fabula, que chamado Momo, para censurar as obras de Neptuno, Minerva, \& Vulcano, condenàra o touro, que Neptuno fizera, dizendo que não havia este animal de ter as pontas na cabeça, mas diante dos olhos, para dar as cornadas mais certas; que a casa de Minerva não fora bem edificada, por quanto não era movediça, para se transferir, ou moverse ao redor, \& virar a

\footnotetext{
9 Veja-se Gerado MANRIQue FríAs, Los mitos clásicos en los dramas mitológicos de Calderón de la Barca. Estudio de sus referencias básicas: personajes y lugares, tese de doutoramento, Universidad Nacional de Educación a Distancia, Madrid, 2010, págs. 250-251. Entre as obras do dramaturgo do Século de Ouro cujo nome se menciona no título desse trabalho, cumpre referir Apolo y Clímene, já que o vilão Sátiro invoca nela as duas divindades em que procuram proteção os graciosos, Momo e Baco: Qué miro? Por el dios Momo, / Que, asociado del Dios Baco, / Es mi segundo devoto (Johann Georg KEIL (ed.), Las comedias de d. Pedro Calderón de la Barca, t. 3, Leipzig, Brockhaus, 1829, pág. 533).
} 
A PROPÓSITO DE MOMO E CORPO CARNAVALESCO:

porta para outra rua, se acaso tivesse algum mao vizinho; \& finalmente que fizera Vulcano mal, de não deixar no peito do homem hum postigo aberto, por onde se podessem descobrir os seus maos intentos; \& como provavelmente as reprehensoens de Momo erão acompanhadas de tregeitos, \& gesticulações, com razão se podem chamar Momos, toda a invenção, \& affectação no gesto, \& trato humano. Tambem poderàs derivar Momo do Grego Mommo, que quer dizer, Máscara, porque tudo no invencioneiro são disfarces, \& apparencias contrarias à realidade ${ }^{10}$.

Nos versos de Joan Baveca e noutros contextos burlescos (ou subversivo-burlescos), podemos ver como o processo de lexicalização do nome próprio em comum não se produz apenas por uma relação analógica, mas também metonímica: parte-se da semelhança entre as bochechas avultadas da caraterização da face de um deus / rei Momo descido à terra como figura mascarada e hilariante a partir da conexão de bochechas e glúteos como pontos da anatomia carnudos, musculados e arredondados. A superabundância, o exagero e a confluência das partes altas da anatomia humana com as baixas são elementos consubstanciais ao discurso carnavalesco na construção da transgressão ou subversão da ordem oficial e provocação do riso libertador. Trata-se de uma combinação de opostos corporais que ultrapassa quaisquer barreiras cronotópicas ou artísticas, como bem se evidencia, por exemplo, no livro Conjunciones y disyunciones (1969), de

\footnotetext{
${ }^{10}$ Vocabulario Portuguez e Latino, Coimbra-Lisboa, Colégio das Artes, Pascoal da Sylva-Joseph Antonio da Sylva-Patriarcal Officina da Musica, 1712-1728, s.v. E, embora fique longe do nosso objetivo passar aqui em revista as propostas etimológicas e os parentescos derivacionais indicados acerca da forma momo em diversas línguas, devemos chamar a atenção sobre a identificação da sua origem como onomatopeica por parte de alguns estudiosos. Assim, a ideia de que "the origin is imitative, from the sound mum or mom, used by nurses to frighten children" e outras formulações semelhantes ou próximas são recolhidas por Enid WELSFORD em The Court Masque: a study in the relationship between poetry and the revels, Cambridge, University Press, 1927, pág. 31. Por sua vez, o filólogo suíço Wilhelm MEYER-LuBKE aponta para uma onomatopeia que remeteria para "careta" -com o significado de gesto burlesco da boca ou do rosto?-, rejeitando uma procedência germânica, mas considerando o grego momos como alicerce questionável ou duvidoso (veja-se a sua obra Romanisches etymologisches Wörterbuch, Heidelberg, Carl Winter's Universitätsbuchhandlung, 1935, pág. 45). Seguindo precisamente as notas explicativas desse estudioso, Carmelo Zulli, na sua edição crítica da produção de Joan Baveca, atribui ao termo em foco a qualificação de "parola onomatopeica" (Johan Baveca. Poesie, Bari, Adriatica Editrice, 1977, pág. 163). Tem-se sublinhado, ainda, a ligação mimo-momo, reconhecendo um indício de fonossimbolismo na alternância vocálica a partir da diferença de conteúdo evocativo das vogais i/u: enquanto o primeiro se envolveria de seriedade, o segundo implicaria grosseria, segundo Joan Corominas e José Antonio Pascual no Diccionario Crítico Etimológico Castellano e Hispánico, Gredos, Madrid, 1980-1991, s.v.) que não deixa de lembrar, no entanto, o sentido de mimas como meretriz; o de mimárion como bordel; e o de mimaritiae como gestos libertinos ou palavras meretrícias. Em qualquer caso, devemos voltar a insistir: nem na documentação medieval nem nos dicionários de alcance galego-português nem ibérico nem panrománico se encontra momo com o significado a partir do qual o jogral galego o equipara e coloca paralelamente a traseiro.
} 
Octavio Paz. O escritor mexicano parte de uma gravura do seu conterrâneo, José Guadalupe Posada, em que uma criatura anã, virada de costas para o espectador, mostra, no lugar das nádegas, um rosto, e detém-se na análise do texto Gracias $y$ desgracias del ojo del culo (1626), de Francisco Quevedo. O autor espanhol de Seiscentos estabelece a comparação entre a cara e o traseiro, que considera merecedor de maiores elogios por ter apenas um olho, como os cíclopes, que "descendían de los dioses del ver"11.

Assim como a dissolução de oposições (superior versus inferior, anterior versus posterior, masculino versus feminino) nos situa num mundo ao revês, a ênfase da caraterização cómica reside precisamente no que se abre ao exterior ou penetra nele através de orifícios, protuberâncias, ramificações e excrescências. A uma série de órgãos como a boca aberta, os seios ou o traseiro une-se o nariz, uma das mais tradicionais e vigorosas fontes de zombaria, que amiúde aponta para o âmbito referencial da sexualidade, para o membro viril. Como sublinha Mikhail Bakhtin, este é um dos motivos grotescos mais difundidos na literatura universal "e em quase todas as línguas, assim como no fundo geral dos gestos injuriosos e degradantes. O nariz sempre é o substituto do falo"12. A crença atingiu tanta difusão que o eminente Laurent Joubert, assistente pessoal de Catarina de Medici e um dos médicos de Henrique III da França e da rainha de Navarra, esposa de Henrique IV, escreveu, em pleno século XVI, uma obra contra certas superstições, embustes e patranhas sob o título Erreurs populaires (1578), na qual se detém a denunciar a absurdeza da vinculação nasal-genital, fortemente consolidada no espírito popular ${ }^{13}$.

$\mathrm{E}$, de facto, podemos dizer que, no corpus da lírica galego-portuguesa, estabelece-se um diálogo entre cantigas à volta do binómio traseiro-nariz, pondo de relevo o significado figurado de pénis que atribui a essa parte saliente da cara.

\footnotetext{
11 Veja-se Octavio PAZ, Conjunciones y disjunciones, Barcelona, Seix-Barral, 1991, págs. 11-12. Para uma reflexão nesse sentido, pode consultar-se Yara FrATESCHI VIEIRA, "Retrato medieval da mulher: a bailarina com pés de porco", Estudos Portugueses e Africanos, 1 (1983), pág. 100.

${ }^{12}$ A cultura popular na Idade Média e no Renascimento: o contexto de François Rabelais, São Paulo, Hucitec / Brasília, Editora da UnB, 2000, págs. 351-352.

${ }^{13}$ Lembre-se que ele é também o autor de um dos mais célebres estudos sobre o riso durante o Renascimento, Traité du ris, contenant son essance, ses causes, et mervelheus effais, curieusemant recerchés, raisonnés et observés, cuja publicação aparece datada em Paris em 1579, embora pareça ter existido uma primeira edição em 1560, seguida de outras duas, em 1567 e 1574, que se perderiam. Seguindo a linha de análises de perfil médico-filosófico que dominava na época, cita ali mais de noventa autoridades gregas, latinas, hebreias e árabes, assim como outras coetâneas. Em palavras do próprio Laurent Joubert, a "matière ridiculez" ou "chose ridiculez" penetra pelos canais próprios dos sentidos da visão e da audição e chega ao coração, órgão responsável "por todas as reações do corpo, desde a agitação do diafragma, passando pela voz entrecortada, a contração dos músculos da face, a abertura da boca, a vermelhidão do rosto, o advento de lágrimas, até a agitação de ombros, braços, peito e pernas, a dor na barriga e a incontinência urinária e de ventosidades, para citar apenas os efeitos mais comuns" (Verena AlBERTI, "O riso, as paixões e as faculdades da alma", Textos de História, 3, 1 (1995), pág. 17).
} 
A PROPÓSITO DE MOMO E CORPO CARNAVALESCO:

Assim, o jogral galego Pero d'Armea (B 1602, V1134) rebaixa e compara o rosto de uma vaidosa mulher com o seu traseiro se a este lhe pusessem produtos de maquilhagem de cor vermelha e branca (concela e alvaiade, respetivamente), assim como umas orelhas e sobrancelhas fingidas:

quem aо теи си pusesse uma cor vermelha, vencer-vos-ia, de tão bonito (...); mas logo que o meu cu estiver bem disposto e puser um pouco de pó branco, remirar-se-á convosco no espelho (...); não vos ficaria a dever em nada na boa aparência ${ }^{14}$.

Tal mofa, criada a partir do desenho poético de um disfarce carnavalesco, provoca o comentário do conterrâneo Pero d'Ambroa, que aponta para a necessidade de introduzir o nariz como elemento indispensável na comparação da cara com a região das nádegas. Se faltar esse órgão saliente, perde-se toda a semelhança: tod'est', amigo, soubestes perdeer / polos narizes que lhi nom poseste (B1603, V1135). Como se vê, os personagens enunciadores mantêm uma atitude de superioridade em relação aos receptores, atribuindo-lhes uma "anomalia" de perfil anatómico, comportamental, sexual etc.; e, segundo Francisco Nodar Manso, avoluma-se a "agresión burlesco-obscena con acciones mimo-gestuales (...) y el público moriría de risa viendo las múltiples peripécias que haría Pedro de Armea para que la 'nariz'encajase en sus nalgas"15.

Enquanto nos versos de Joan Baveca nos deparamos com uma maior ênfase semântica em relação à impetuosidade física por meio de "britar" e "quebrantar", aqui recorre-se ao verbo "pôr"; mas, em qualquer dos casos, a sátira orienta-se para a homossexualidade. Na verdade, constitui este um motivo tão frequente que a simples menção da parte posterior do corpo masculino -independentemente do toque irónico com que se formule-conduz logo a uma leitura sob o prisma da sodomia. Apesar da ausência dos dois verbos utilizados pelo primeiro dos jograis galegos em recolhas de eufemismos/disfemismos ou do jogo de equívocos que se vinculam a práticas carnais, cabe defender o seu funcionamento tanto numa direção hetero-, quanto homossexual. Aliás, embora Ruth Mazo Karras e Jacqueline Murray ${ }^{16}$ falem do desconhecimento de alusões concretas à felação em textos da Europa medieval, Carlos Callón ${ }^{17}$ aponta para algumas possibilida-

\footnotetext{
${ }^{14}$ Eis a paráfrase que da cantiga faz VIEIRA em "Retrato medieval da mulher...”, pág. 98.

15 Teatro menor galaico-portugués, siglo XIII, Reichenberger, Kassel, pág. 172 -e, acreditando nessa atividade mimo-gestual que acompanharia a interpretação das cantigas galego-portuguesas, o mesmo riso provocaria, evidentemente, o nariz de Pero d'Ambroa a querer entrar no momo/cu do estalajadeiro referido por Joan Baveca (B 1457, V 1067).

16 "The Sexual Body", em Linda Kalof (ed.), A Cultural History of the Human Body in the Medieval Age (500-1500), London, Bloomsbury, 2010, págs. 59-75.

${ }_{17}$ As relacións sexoafectivas intermasculinas e interfemininas no trobadorismo galego, tese de doutoramento, Universidade da Coruña, 2017, pág. 273.
} 
des da sua presença em cantigas galego-portuguesas que remetem para pelejas intermasculinas interpretáveis como sexuais. É nessa linha que chama a atenção sobre a referência que Airas Perez Vuitoron faz à face britada, imputando uma série de malfeitorias ao adiantado Correola ${ }^{18}$ e comentando: "e quen quiser à peleja volver, / log'entrad'i e, a vosso poder, / vós said'én con o rostro britado" (B 1482, V 1093).

Outra hipótese relativa à prática do sexo oral viria dada ainda, segundo o citado investigador, pelo cantar que o nosso Joan Baveca dirige a um Bernal Fendudo -talvez Bernal de Bonaval, cujos comportamentos inspirariam a alcunha e diversas zombarias- para anunciar-lhe que, perante um combate com os mouros,

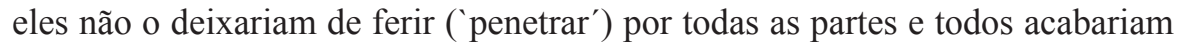
morrendo no seu poder (B 1453, V 1063). A propósito do uso do termo quebrantar e da expressão cuu quebrantado no âmbito de advertência e/ou pagamento na cantiga de Joan Baveca que contém a única ocorrência a momo da nossa poesia medieval, cabe lembrar também os versos em que o trovador Gonçal' Eanes do Vinhal (V 1000) fala sobre um dos seus homens de armas, Pero Fernandez, retratado como presunçoso e de fingida virilidade. Aitor Rivas refere-se a esse texto, de facto, como exemplo da "temática de la compra de sexo entre hombres"19, pois, dado que o personagem não traz dinheiro para liquidar o imposto de portagem aos porteiros nas terras do visconde Gaston IV de Béarn, utilizará outros modos para tais efeitos: se lhi peagen pedir o Gaston, / peage de cuu pagará $i$.

E, se Pero d'Ambroa se poderá sentir compensado com a penetração dos narizes no momo do albergueiro que não cumpre o combinado (B 1457, V 1067), a disponibilidade de Pero Fernandez para a prática dessa ação homoerótica justifica-se ironicamente pelo seu grande empenho na infração da ordem (e, com 'é ome de gran coraçon), assim como pela sua ardura e o fervor do sangue: ca el ven quebrando con grand'ardura / con este mandado que oiu ja / e ferve-lh'o sangui e fara loucura). Quando os cobradores do citado visconde lhe exigirem cumprir a ordem de remuneração, fará com que bevan peagen que lhis el dara (V 1000).

Na verdade, o próprio termo mu ('mulo'), que se regista já no início da composição de Gonçal'Eanes do Vinhal e constitui um dos elementos de animalização mais frequentes na sátira aos homossexuais, sugere uma leitura que ultrapassa o sentido escatológico que defende Antonia Víñez Sánchez quando fala de

\footnotetext{
${ }_{18}$ Para observar o jogo semântico de que é objeto a palavra desse cargo governativo nas cantigas, pode consultar-se, entre outros, Simone MARCENARO, L'equivocatio nella lirica galego-portoghese medievale, Alessandria, Edizioni dell’Orso, 2010, pág. 152.

19 "O que veer quiser, ai cavaleiro, / Maria Pérez, leve. Algum dinheiro: amor, dinero y género en las cantigas gallego-portuguesas”, em Inga Baumann e Slaven Waelti (eds.), Vom Liebespfand zur Singlebörse Über die ökonomische Rhetorik der Liebe, Berlin, Lit Verlag, 2019, pág. 83.
} 
A PROPÓSITO DE MOMO E CORPO CARNAVALESCO:

peage de cu como metáfora dos excrementos que Pero Fernandez "utilizará, si lo enfurecen, como pago del impuesto" ${ }^{20}$. Para além da compensação via sexual, não podemos deixar de notar certas coincidências entre ambas as cantigas em pontos específicos, tais como o cenário geográfico em que se desenvolvem os acontecimentos - as terras de além Pirenéus- e a remissão para uma oposição em termos gentílicos entre franceses e espanhóis. Nas duas composições se sublinha, ironicamente, a "ousadia" mostrada fora das fronteiras setentrionais da Península Ibérica pelos últimos: no primeiro caso, através da alusão ao medo que Pero d'Ambroa deverá deixar com o britar/quebrantar dos seus narizes no momo/cu; no segundo, pela lembrança de um ome d'Espanha morto pelos problemas causados precisamente à volta da peagem demandada ${ }^{21}$.

\section{MOMO NO ÂMBITO DE MASCARAMENTOS E CENIFICAÇÕES DE AFIRMAÇÃO CORTESÃ NO CANCIONEIRO GERAL}

E, chegados a este ponto, temos de voltar à carnavalização baseada na analogia de cariz topográfico-corporal que supõe o momo citado por Joan Baveca a fim de reparar no disfarce ou mascaramento que implicavam certas atividades lúdicas de que a nobreza peninsular participou já desde o século XIII e avançar em direção ao(s) momo(s) do Cancioneiro Geral de Garcia de Resende. Como veremos, no que diz respeito ao uso do vocábulo na vasta compilação quatrocentista, cabe falar de diferentes significados, aparecendo também inserido num contexto do rebaixamento corporal rosto/traseiro ao serviço da descriptio pueri e do riso. Porém, predominam ali as ocorrências que remetem para a tradição profana da (pré)teatralidade, apontando para um espetáculo cuja delimitação como peça dramática autónoma, sujeita a determinadas regras e a um esquema formal único, não resulta fácil. A documentação demonstra que particularmente a corte portuguesa lhes outorgava uma grande importância que foi crescendo com a passagem do tempo, destacando-se o valor que podiam atingir os seus elementos de atrezzo. Os indivíduos representavam-se ali a si próprios ou a outros

\footnotetext{
${ }^{20}$ Antonia Víñez SÁnchez, El trovador Gonçal'Eanes Dovinhal. Estudio histórico y edición, Santiago de Compostela, Universidade de Santiago de Compostela, 2004 (Anexo de Verba. Anuario Galego de Filoloxía, 55), pág. 200.

${ }^{21}$ Embora das cantigas galego-portuguesas não sobressaiam as referências diretas a nacionalidades ou regionalismos, cumpre lembrar aqui uma em que o português Gil Perez Conde (B 1526) se queixa de um castelhano irascível e pelejador - con coraçon, atributo coincidente com o aplicado a Pero Fernandez- , o qual tenta evitar resguardando-se com receio na sua pousada $\mathrm{O}$ conteúdo faz pensar, com efeito, nos inícios da delineação de dois tipos culturais distintos e com uns traços que irão sobreviver no imaginário literário ao longo dos tempos: o português prudente e moderado versus o espanhol, bravo e fanfarrão, tal como lembra Maria Isabel Morán CABANAS em Traje, gentileza e poesia. O campo semântico do moda e da vestimenta no Cancioneiro Geral, Lisboa, Estampa, 2002, pág. 517.
} 
personagens e, longe de qualquer consideração pejorativa, tais divertimentos (ou desenfadamentos) constituíam um símbolo de poder, tendendo a realizar-se com todo o aparato possível.

Assim, temos notícia da doação em herança de uma máscara de ou para momo, propriedade de D. Mafalda, filha do rei D. Sancho I e D. Dulce de Aragão, efémera rainha de Castela pelo seu contrato de casamento com o monarca Henrique I e, depois, freira, superiora e reformadora do convento de Arouca. Eis o seu testamento, datado no ano de 1256, em que deixa, entre outros produtos de extraordinário valor, a sua melhor máscara ao seu irmão D. Pedro, conde de Urgell:

\begin{abstract}
Item ifanti Domino Petro frati meo meum momum, et lapidem sapi, et aliam sortellam magnam et smaragdam [...] Item quod superius dixi de manda Germani Infantis Domini sic muto et declaro. Mando ei meum momum optimum quadratum et aliam petram quadratam et simileter aliam petram de sigillo, quas desero ad cellum et unum speculum optimum et habet virtutem contra paralisim et unum Corallum optimum et unam masanam Alambre optimam ${ }^{22}$.
\end{abstract}

O momo designava tanto a representação quanto os personagens que participavam a modo de gigantes, monstros, animais fabulosos, etc., todos eles caraterizados com vistosos trajes, jóias e outros acessórios ${ }^{23}$. A sua movimentação

\footnotetext{
22 António Caetano DE Sousa, Provas da história genealógica da casa real portuguesa, vol. 1, [s. 1], Oficina Silviana da Academia Real, 1739, págs. 32-33 (o sublinhado é nosso). Eis uma boa ilustração das possibilidades que fornecem estes documentos como úteis fontes para a construção da história social e das mentalidades e como ferramenta auxiliar no estudo do imaginário literário. Para citar apenas um caso recente e especialmente interessante que passa em revista as estratégias de pesquisa, as metodologias e o multiperspetivismo aplicável à prática testamentária na Idade Média, consulte-se o artigo de Pablo S. Otero Piñeyro Maseda e Miguel García-Fernández, "Los testamentos como fuente para la historia social de la nobleza. Un ejemplo metodológico: tres mandas de los Valladares del siglo XV", Cuadernos de Estudios Gallegos, vol. 60, núm. 126 (2013), págs. 128-138. Lembremos, aliás, que o primeiro testemunho da existência de espetáculos (pré)teatrais no noroeste peninsular parece ser um documento datado de 1193 em que precisamente o citado progenitor de D. Mafalda faz doação de terras a dois irmãos jograis (Bonamis e Acompaniado), que o recompensarão com um arrimidilium, (espetáculo baseado em contrafazer gestos, voz, formas de andar etc.). Veja-se, por exemplo, Pilar LoRENZo GrAdín, "Teatralidad y teatro medievales en el occidente peninsular", Revista de lenguas y literaturas catalana, gallega y vasca, 4 (1944-1995), págs. 87-105. E temos de agradecer aqui, particularmente, a oportunidade de conhecer a obra, atualmente no prelo, de Maria do Amparo Tavares MALEval, O teatro medieval e seus congêneres em Santiago de Compostela (séculos XII-XIII), Niterói, Eduff, em que se aborda um vasto panorama de elementos e atividades espetaculares dos âmbitos profanos e religiosos das datas mencionadas.

${ }^{23}$ Nesse sentido, se na nota 10 já fizemos referência à associação mimo-momo aludida por lexicógrafos, vale a pena revisitar agora a explicação do termo mimoso fornecida por Rafael BLUTEAU: Na opinião de Manoel de Faria, tomàrão os Portuguezes estas palavras Mimo, \& Mimoso, de Mimos, Pantomimos, \& Archimimos, que erão representantes, nos quaes tudo saõ ficçoens, \& arremedos da verdade; que he a
} 
implicava, por vezes, uma maquinaria engenhosa e os argumentos mais comuns eram inspirados no mundo aventureiro e cavaleiresco, desenvolvendo-se numa sucessão de quadros plásticos com música e dança. No entanto, o texto literário ou as expressões pronunciadas assumiam apenas um status periférico, tal como acontecia noutras manifestações que constituíam partes incorporadas em estruturas festivas de dimensão mais ampla durante a Idade Média ${ }^{24}$. Parece que o espetáculo em questão foi mais frequente no âmbito das cortes régias, onde se programavam pormenorizadamente desde a duração até os convidados. Ora, há também constância de tal atividade histriónica noutros espaços e, de facto, nas Constituições Sinodais de Braga, promulgadas em 1477 por Luís Pires, estabeleceu-se que nem eclesiásticos nem seculares ousassem ou consentissem nas igrejas os seguintes entretenimentos: jogos, momos, cantigas, nem bailhos, nem se vistam os homens em vistiduras de molheres nem molheres em vestiduras de homens ${ }^{25}$.

Quanto ao Cancioneiro Geral, extraordinário viveiro de usos e costumes dos cortesãos de Quatrocentos, a referências aos momos como modos de representação (pré)teatral aparece explícita já no prólogo sob a consideração de entretenimentos que, pelo seu carácter civilizacional e cultural, se tornavam dignos de serem preservados na memória através da escrita:

E assi muitos emperadores, reis e pessoas de memória, polos rimances e trovas sabemos suas estórias e nas cortes dos grandes Príncepes é mui necessária na gentileza, amores, justas e momos

\footnotetext{
razão por que chamàrão os Gregos ao Bugio Mimo. E acrescenta o dito Author, que Mimos, \& Momos se chamão em Portugal os que se achavão em algüa festa, ou banquete disfarçados com mascarilhas, fazendo acções, \& gestos como succede ao melindroso. Chamou Aristoteles Bobo ao mocho, só porque sempre está fazendo figuras; \& traz Pierio por symbolo dos Representantes, ou Comediantes a esta Ave, por causa dos gestos, que costuma fazer; \& isto he o que succede aos que chamamos Mimosos, que nos fazem rir com seus melindres, \& elles mesmos se estão rindo com suas tristezas, porque saõ affectadas demasias do que logrão de gostoso. De sorte que Estar mimoso val o mesmo, que Estar fingido, \& contrafeito, \& conforme à sua origem de momo, ou mimo, se pòde dizer Momoso, como Mimoso (Vocabulario Portuguez e Latino, s.v.).

${ }^{24}$ Vejam-se, entre outras, Maria Isabel Morán CABAnas, Festa, teatralidade e escrita. Esboços teatrais no Cancioneiro Geral de Garcia de Resende, A Coruña, Biblioteca Arquivo Teatral Francisco PilladoMayor / Universidade da Coruña, 2003 ou as recentes informações de Tatiana JoRDÁ FABRA, Hacia el actor profesional en el teatro peninsular del Renacimiento, tese de doutoramento, Universitat de Valência, 2015, pág. 52. Aliás, não podemos deixar de referir o estudo capital de Eugenio AsENSIO sobre as mascaradas na corte portuguesa, "De los momos cortesanos a los autos caballerescos de Gil Vicente", em Estudios Portugueses, Paris, Fundação Calouste Gulbenkian, 1974, págs. 25-36, assim como o capítulo introdutório para uma história dos espetáculos de tradição profana anterior a Gil Vicente em José Augusto Cardoso Bernardes, Sátira e lirismo. Modelos de síntese no teatro de Gil Vicente, Coimbra, Universidade de Coimbra, 1996, págs. 66-90.

25 Apud Ana María Álvarez Pelliteiro, “Aproximaciones al estudio del teatro medieval en España”, El Crotalón, 2 (1985), pág. 32 (o itálico é nosso).
} 
e também para os que maus trajos e envenções fazem, per trovas sam castigados e lhe dam suas emendas, como no livro ao adiante se verá. E se as que sam perdidas dos nossos passados se puderam haver e dos presentes se escreveram, creo que esses grandes Poetas que per tantas partes sam espalhados não teveram tanta fama como têm ${ }^{26}$.

Na coletânea recolhe-se, de facto, um par de breves ou letras, textos reduzidos ao mínimo, que acompanham uns momos cuja temática obedece ao código do amor cortês. Um deles aparece dedicado por Francisco de Portugal, Conde do Vimioso, a uma senhora com que se desaveio e, segundo se indica na correspondente rubrica - convertida numa verdadeira acotação teatral ${ }^{27}$-, conta com a intervenção de dois personagens fictícios no jogo cénico, o Diabo e o Anjo, entregando este último os versos à destinatária: e ho anjo deu esta cantigua a sua dama (II, núm. 300). Ambos os dois são mudos na representação, construída a modo de uma alegoria evocativa das experiências de Cristo: o amante tenta manter-se fiel e firme perante as provocações do demónio, sendo possível que acompanhassem a leitura do breve (prosa e cantiga) através da mímica. O outro breve é da autoria de Pedro Homem, estribeiro-mor do rei D. Manuel I e proprietário do Cancioneiro da Ajuda ${ }^{28}$ no século XV, cuja epígrafe apenas diz: Breve que fez Pedro Homem a uns momos (I, núm. 174), sem fornecer informações sobre as causas particulares que o fizeram nascer. Somente se destaca ali a alusão ao serão como lugar de representação: Sam-nos mui boons os seräaos para ver e desejar / e momos para tomar.

Por outro lado, do poeta Rui de Sousa, escudeiro de D. Fernando, o Infante Santo, e membro da casa de D. Afonso V, diz-se que é um grande fazedor de momos (I, núm. 97), cenificações com que amenizaria as horas de lazer do paço -porém, não temos desses nenhuma notícia. Mais significativos resultam, portanto, os versos destinados ao canto e abertos com o mote Alta Rainha, Senhora, / Santiago por nós ora (IV, núm. 734) que Pero de Sousa Ribeiro, membro do

\footnotetext{
${ }^{26}$ Para a transcrição do prólogo e dos textos do Cancioneiro Geral seguimos, ao longo de todo o artigo, a edição de Aida Fernanda DiAs, Cancioneiro Geral de Garcia de Resende, Maia, Imprensa Nacional-Casa da Moeda, 1998, indicando, no caso dos segundos, os correspondentes números de volume e composição. O itálico é nosso.

${ }^{27}$ Patricia BоттA, "Las rúbricas en el Cancioneiro Geral de Resende II", em Mercedes Pampín Barral e Carmen Parrilla García (coords.), Actas del IX Congreso Internacional de Asociación Hispânica de Literatura Medieval, vol. I, A Coruña, AHLM, 2005, págs. 489-505. Veja-se, igualmente, Valeria Tocco, Poesias e sentenças de D. Francisco de Portugal - $1^{\circ}$ Conde de Vimioso, Lisboa, Comissão Nacional para as Comemorações dos Descobrimentos Portugueses, Lisboa, 1999.

${ }_{28}$ Maria Ana Ramos, "Invoco el rrey Dom Denis... Pedro Homem e o Cancioneiro da Ajuda", em Santiago Fortuño Llorénse e Tomàs Martínez Romero (eds.), Actas del VII Congrès de la Asociacion Hispanica de Literatura Medieval, vol. I, Castelló de la Plana, Universitat Jaume I, 1999, págs. 127-179.
} 
A PROPÓSITO DE MOMO E CORPO CARNAVALESCO:

Conselho de D. Manuel, criou para um sengular momo em Santos, o qual teria lugar quando El-Rei nosso Senhor veo de Santiago, quer dizer, com motivo da peregrinação de um monarca português a Santiago de Compostela, segundo se diz na rubrica que os acompanha. Embora os estudiosos nem sempre tenham coincidido na identificação nem datação dessa visita ao Apóstolo, tudo parece indicar que se trata da feita por D. Manuel em 1502, depois da qual foi recebido pela rainha nos Paços de Santos-o-Velho, em Lisboa, com muita alegria e alvoroço $^{29}$.

Porém, se voltarmos o olhar para a tradição satírica medieval, o que mais nos interessa aqui é observar o uso da forma momo ao serviço de uma caraterização individual que privilegia a hilaridade entre os objetivos visados. Nesse sentido, já vimos que no prólogo do Cancioneiro Geral se destaca a atenção sobre a indumentária, explicitando-se mesmo a intenção de castigar através do riso os que envergam maus trajos e envenções ${ }^{30} \mathrm{e}$, com efeito, são muitos os deselegantes que se tornam alvo de mofa a partir de tal motivo, entre os quais se incluem os atores/personagens dos espetáculos cortesãos. Assim, as vestes envergadas para a cenificação do momo, apesar do valor da matéria prima utilizada na sua confeção, receberam os dardos de Francisco de Viveiro, que informa sobre António da Silva nos seguintes termos: Fez de ouro, prata e seda / e de moeda / u mao vestido de momo (III, núm. 371). Cumpre referir que, por exemplo, na Crónica da Tomada de Ceuta (1450), de Gomes Eanes de Zurara, também nos deparamos precisamente tanto com o valor metonímico de vestido para a representação -e, portanto, equiparado à categoria de libré, espécie de casaco que levava, via de regra, alguma divisa do senhor que a tinha oferecido ou daquele a que se pretendia mostrar fidelidade e homenagem- como com o de espetáculo. Observe-se a presença de ambos no seguinte trecho, em que o cronista nos fornece informações acerca das celebrações do infante D. Henrique em Viseu, em 1414, perante o consentimento dado pelo seu pai, para uma intervenção bélica no norte da África:

\footnotetext{
${ }^{29}$ Vejam-se os estudos de Jerónimo OsóRIO, Da vida e feitos d'el-rei D. Manuel I, Porto, Livraria Civilização, 1944 e José MARQues, “Os Santos dos Caminhos Portugueses”, Revista da Faculdade de Letras, III, 7,1 (2006), págs. 243-262. Pense-se que as entradas dos soberanos se envolviam de todo um cerimonial de triunfo que lhes conferia uma múltipla dimensão: social, política, religiosa, estética... e que obedecia "a uma ritualização topográfica muito precisa, centrando-se no trajecto entre a porta da cidade (símbolo de princípio de ordem e do fim da imprecisão rural e do caos) e a igreja ou o palácio, passando pela rua principal, que funciona como eixo vertebrante da personalidade da urbe" (cf. CARDOSO BERNARDES, Sátira e lirismo..., pág. 72).

${ }^{30}$ Maria Isabel MorÁn CABANAS, "Riso e traje, uma combinação recorrente no Cancioneiro Geral", em Elisa Nunes Esteves, Isabel Barros e Margarida Reffóis (coords.), O riso: teorizações, leituras, realizações, Lisboa, Caleidoscópio, 2015, págs 147-165.
} 
E para isto mandou o Infante a Lisboa e ao Porto por panos de sirgo e de lã e broladores e alfaiates para fazerem suas librés e momos segundo para sua festa realmente pertencia. E desi viandas foram buscadas por todas as partes, mais abastadamente que se puderam achar. Ali foram trazidas muitas carregas de cera que se despenderam em muitas tochas, assim de servir como de danças, brandões e velas e contos em tamanho número que quase seria impossivel de se poderem contar (...). Ali houve momos de tão desvairadas maneiras, que a vista deles fazia mui grande prazer a quantos ali eram, e ainda a muitos de for que o souberam ${ }^{31}$.

A aplicação de momo no Cancioneiro Geral que mais nos interessa no presente estudo está ligada, ainda, à descrição do corpo do próprio Garcia de Resende sob uma perspetiva carnavalesca, integrando-se numa vasta série de versos que traçam o seu retrato. O célebre compilador deixou-nos, com efeito, boas amostras do seu espírito animado e temperamento humorístico, contribuindo não só com textos da sua autoria para enriquecer a obra, mas também incluindo ali coisas de folgar inspiradas precisamente no seu visual e nas suas atividades artístico-lúdicas, quer dizer, na sua aparência de momo para divertir em festas do paço (IV, núm. 879). Na verdade, ao longo de toda a coletânea, a troça pessoal sobrepõe-se à de costumes, tem um alcance imediato e ninguém escapa dela, independentemente da sua menor o maior categoria social, fazendo com que o interesse do público recaia tanto na mensagem quanto na figura alvejada. E, no que diz respeito à caricatura poetizada de Garcia de Resende, sobressaem particularmente uns traços físicos discordantes com o cânone de beleza na altura e a excentricidade na exibição de talento e donaire. Os autores, através de fórmulas expressivas que entroncam, em certa medida, com a tradição de escárnio e maldizer, pretendem fazer gala de perícia vocabular e estilística, apoiando-se, sobretudo, em duas series léxicas: uma relativa às dimensões desmesuradas do corpo e a outra à produção de ruídos estridentes ou mal soantes. Se em 2002 comentávamos:

Desde sempre foi reconhecida pelos investigadores a necessidade de empreender a análise do léxico da compilação resendiana que foi veiculo de expressão dos autores nela representados. Apesar de que algumas tentativas foram já feitas neste sentido, muitas dúvidas não conseguiram ser esclarecidas, quer dizer, ou não se encontrou qualquer explicação para muitos dos vocábulos enig-

${ }^{31}$ Reis Brasil (ed.), Crónica da Tomada de Ceuta, Lisboa, Europa-América, 1992, págs. 100-101. 
A PROPÓSITO DE MOMO E CORPO CARNAVALESCO:

máticos, ou as diversas significações propostas não encaixaram cabalmente nos contextos em que se integram ${ }^{32}$.

hoje, passados quase vinte anos desde então, podemos afirmar o mesmo, pois os poetas do Cancioneiro Geral sentiram predileção pela elaboração de versos carregados de dificuldades e conferidores de um carácter hermenêutico. É claro que não é nas composições de temática amorosa onde se registam as maiores dificuldades de leitura e interpretação: tal como acontece nas cantigas de amor e de amigo galego-portuguesas, o vocabulário remete aí para estados sentimentais e experiências que tendem a repetir-se; em contrapartida, a riqueza e variedade terminológico-conceptual de escárnio e maldizer e dos textos satíricos e coisas de folgar de Quatrocentos apresentam-se-nos amiúde obscuros. Na sátira trovadoresca são copiosas sobretudo as referências às relações sexuais e aos órgãos genitais que não se veiculam através de linguagem direta, mas de procedimentos na esfera da aequivocatio, à qual se refere precisamente a Arte de Trovar quando fala de palavras cobertas ou de dous entendimentos ${ }^{33}$. Por sua vez, no Cancioneiro Geral são emblemáticos termos como agudo /agudeza e inventor/invenção no que diz respeito à vontade de demonstrar a competência poética e perspicácia retórica perante a Corte. Tanto num como noutro caso, é elevado o número de textos que interagem num circuito física e socialmente bastante fechado; e, nos dias de hoje, não dispomos de acesso direto a chaves para a interpretação que o público de então conhecia.

\section{AD VITUPERIUM CORPORIS ET ARTIS: MOMO E RETRATO CARNAVALESCO DE GARCIA DE RESENDE À LUZ DA SÁTIRA GALEGO-PORTUGUESA}

A série de versos motejadores da figura de Garcia de Resende em que se inclui a forma momo aparece ditada pelo empenho em criar, adaptar e amontoar insultos sobre insultos até situar-nos, humoristicamente, perante o indivíduo com a pior compleição física da corte portuguesa. Podemos dizer que este personagem substitui, portanto, o galego Pero da Ponte das cantigas medievais, pois o trovador conterrâneo Afons' Eanes do Coton, ao comparar as silhuetas de três maljeitosos (ou contrafeitos) - a deste, a dele próprio e a de um João Fernan$\operatorname{des}^{34}$ - conclui que a do primeiro supera todas as outras em deformidade: pero

\footnotetext{
32 Cf. Maria Isabel Morán Cabanas, Traje, gentileza e poesia..., pág. 18.

33 Para comprovar o relevo que atinge aqui a questão sexual como motivo poético, pode consultar-se o volume de Xosé Bieiro Arias FreiXedo, Per arte de foder. Cantigas de escárnio de temática sexual, Berlin, Frank \& Time, 2017.

${ }^{34}$ Trata-se de um indivíduo apodado também pela sua fisionomia e semelhança com um mouro noutras composições. A partir de tal circunstância recorre-se, com efeito, a jogos de equívoco, através da
} 
mal talhados somos nós, / s'omen visse Pero da Ponte en cós, / semelhar-lh'-ia moi peor talhado (B 1616, V 1149). E, voltado o nosso olhar para a combinação das duas series léxicas acima mencionadas -proporções excessivas do corpo e emissão de ruídos retumbantes-encontramos um caso paralelo à descriptio ou denigratio pueri de Garcia de Resende na cantiga que o trovador Fernan Paez de Tamalancos dirige ao jogral Saco. Conforme se indica na rubrica da tradição manuscrita, este apenas teria de ser designado como Saco, nome ou alcunha muito significativa que nos remete para a grande dimensão das suas nádegas e a inaptidão para tocar a cítola (B 1334, V 941):

Don Fernan Paez de Talamancos fez este cantar de maldizer a un jograr que chamavam jograr Saco, e era mui mal feito; e por entrobou-lhi que mais guisad'era de seer Saco ca jograr.

(...)

Quem a vós chamou jograr a pran mentiu, ca vej'eu que citolar non vos oío nen os vossos nadigões nonos viu.

Vosso nome vos dira, assi Deus m'ampar, quen vos chamar saco e non jograr.

Para além do mais mal jeitoso do Cancioneiro Geral, Garcia de Resende é também uma espécie de "intérprete saco" ou, para citar literalmente os versos que a ele se lhe dedicam, uma "saca de algodão" (IV, núm. 879) -sublinhe-se, no entanto, que das mofas quatrocentistas se exclui qualquer consideração da dimensão socioprofissional ligada à crítica aos jograis nas cantigas de escárnio e maldizer, abrangendo autores como Lourenço, Lopo o Martin Galo ${ }^{35}$-.

Precisamente em relação aos cânones da estética nos tempos da compilação portuguesa, é preciso lembrar o apogeu que atingiu a chamada «linha X» nos

expressão talhar a saia (B 1370, V 978), utilizada por Martin Soarez tanto para indicar que com a peça que lhe cortaram ainda parece peior talhado, como para aludir, de modo indirecto, à prática islâmica da circuncisão. Outrossim, os versos de Roi Gomez de Briteiros giram à sua volta, sublinhando os seus traços de "crespo e mal talhado" (B 1544) e a sua condição de anaçado, com o sentido de convertido a outra religião.

${ }^{35}$ Após uma observação pertinente e rigorosa do tecido textual dos versos de Fernan Paez de Tamalancos acima transcritos e doutros da mesma autoria, que descansa sobretudo no constante jogo do equívoco a partir do nome do jogral e a família léxica de medir, Carlos Paulo MArTínez Pereiro fala de um "descualificador, seguro e diáfano ataque de base nominal a un obeso xograr, polas súas incapacidades interpretativas e polas súas desmedidas pretensións petitorias", assim como de um "denigrador, probábel e opaco ataque, tamén de base nominal, pola homosexualidade na desmesura das suas nádegas" ( $A$ indócil liberdade de nomear. Por volta da interpretatio nominis na literatura trovadoresca, A Coruña, Espiral Maior, 1999, pág. 187). 
A PROPÓSITO DE MOMO E CORPO CARNAVALESCO:

finais da Idade Média, que exigia um corpo atlético com largos ombros e tórax, mas com estreita cintura. Conforme diz o poeta Fernão da Silveira numa espécie de manual de etiqueta para triunfar no paço, junto com saber vestir e tratar, é importante ser sobr'alto, alvo, delgado (I, núm. 31). Ora, muito se afastam tais traços do retrato que se desenha de Garcia de Resende a partir de um longo processo de coisificação baseado tanto na semelhança do seu corpo com objetos arredondados e/ou recheios de algum material como na metonímia por meio da comparação com um fabricante desses produtos ou designando toda a sua massa anatómica através de uma parte saliente e especialmente avultada. A obesidade, anátema na era dos manequins dos serões do século XV, assume um papel essencial na representação do corpo grotesco como signo da intensa interação com o mundo que o comer e o beber abusivamente proporcionam: o homem degusta o mundo, engole-o, recria-se no seu sabor e enxerta-o no seu corpo ${ }^{36}$.

Assim, a fartura material dos gordos, como os reis-momos carnavalescos, ocupa um lugar de destaque no campo da comicidade. É Afonso de Valente (IV, núm. 879), talvez o tangedor do rei D. Manuel (ou o carcereiro da prisão do Limoeiro de Lisboa referida pelo dramaturgo Gil Vicente no Auto da Barca do Inferno?) que encontra na pessoa de Garcia de Resende mais motivos para o riso. O poeta recorre ao deslocamento topográfico em sentido vertical e sob o prisma carnavalesco que observamos na sátira galego-portuguesa para construir a sua caricatura, definindo-o com um nalguas bochechas, expressão original criada a partir da combinação da partes avultadas da cara e do traseiro ${ }^{37}$. Aliás, nos versos que lhe dedica regista-se uma longa série de equiparações que o identificam com um "homem contentor", destacando-se, entre muitas outras, as que remetem para as sete seguintes imagens:

- Um indivíduo que faz almadraques e seirões, quer dizer, colchões ou almofadas e sacos para o transporte em animais de carga.

- Um ser feito de coxins recheios de um produto tão mole como o cotam.

\footnotetext{
${ }^{36}$ BAKHTin, A cultura popular..., págs. 351-352.

${ }^{37}$ Embora concretamente na prosopografia de Garcia de Resende não caiba falar de referencias à subversão e rebaixamento carnavalesco do nariz-pénis, não podemos deixar de aludir à presença da parte saliente do rosto em certos contextos humorísticos e obscenos do Cancioneiro Geral. Um deles é a mofa a uns gibões com gola de grã (corante vermelho carmim), em que os poetas procuram o riso colocando em posição de rima nomes de elementos avermelhados como lacões (abrasados) e colhoes ou pés de perdizes (entenda-se, da espécie perdiz-vermelha) e narizes (IV, núm. 863) -par rimático que ocorre na cantiga medieval acima comentada de Pero d'Ambroa a Pero d'Armea: E Don Pedro, põede-lh'os narizes / ca vos conselh'eu o melhor que poss[o]: / e mat[a]rei úu par de perdizes (B 1603, V 1135). O outro diz respeito ao nariz grande de um judeu (ele tem nariz de rolha / sobre ter ruim sembrante, II, núm. 392), lugar-comum da caraterização física dos hebreus em Quatrocentos e na literatura posterior.
} 
- Um conjunto de mais de setenta cousas posta em gibam, expressão que hiperboliza a corpulência tanto por meio do determinante numeral como pelo gibão, peça de roupa envergada segundo a moda daquela altura: a modo de camisa forrada de panos a fim de avolumar o peito e deixa cair sem pregas, como se o corpo estivesse cheio de ar.

- Um grande covam de vesugos, ou seja, um cesto de peixes de forma arredondada ou ovalada - de facto, besugo ainda se utiliza hoje em português coloquial como sinonimo de gordo.

- Uma saia de verdugos, ampla saia então muito em voga, munida de enorme armação sobre aros - com efeito, foi conhecida também, em castelhano, como guarda-infantes dada a sua presumível utilização para disfarçar a gravidez das damas.

- Um fardo de pimenta, continente que reproduz igualmente a imagem de saco.

- Um gigante rebordão, designação que lembra a castanha de grande tamanho que nasce a partir da semente do castanho bravio ou silvestre.

Igualmente, João Rodrigues de Sá (vol. IV, núm. 864), alcaide-mor do Porto, modelo da nobreza culta da época e poeta singular pela sua erudição e contribuição ao humanismo em Portugal, colabora na descrição humorística de Garcia de Resende por semelhantes vias. Na sua descrição recorre, de facto, a termos como almofreixe, com o sentido de mala grande ou baúl, ou gram palheiro, apodo que nos traz à mente a cantiga galego-portuguesa de Afonso $\mathrm{X}$ en que se sublinham as volumosas formas de Sancha Anes através da sua comparação com uma mostea, quer dizer, uma carrada de palha: ca nunca vi dona peior talhada, / e quige jurar que era mostea (B 458). E, ainda, outras referências dignas de menção encontramos num texto de autoria coletiva recolhido em nome de Álvaro de Sousa, pajem de lança do rei; Rui de Melo, alcaide-mor de Elvas; Álvaro Barreto, partidário de Afonso V no confronto de Alfarrobeira; Francisco Homem, primogénito de Pedro Homem, acima aludido, e o seu sucesor no cargo de estribero-mor; Francisco da Cunha, acerca do qual não dispomos de dados concretos; e Manuel Correa, cortesão da Madeira, de cuja biografia também não possuímos notícias (IV, núm. 865). Os versos de tal composição até nos apresentam um Garcia de Resende disfarçado ou trasvestido verbal e metonimicamente em forma de bandouva, termo substituido hoje no registo coloquial em português por bandulho para referir o ventre ou barriga: A senhora dona bandouva peço, / por mercê, que me responda.

Para acentuar especificamente a adiposidade e flacidez das carnes do personagem em questão são também várias as comparações estabelecidas com recipientes de líquido do tipo tonel, pipa ou odre apojado como mama. Aliás, ao 
seu gosto pelo vinho parecem aludir expressões como feiçam de cuba, guia de dança de copas ou grega bebada de parto, entre outras. Enfim, os colaboradores do Cancioneiro Geral focam a imagem do compilador como a representação por excelência da superabundância e fartura -farto é, de facto, a palavra em posição de rima com parto na primeira das estrofes abaixo transcritas e, ainda, na esfera do excesso se inclui a embriaguez. E, em consonância com essa ótica carnavalesca, derrubam-se também as barreiras da identidade sexual: o extravasamento implica um mundo às avessas no qual rege a lei de "um contato livre e familiar entre os homens" ${ }^{\prime 38}$.

Todas as frechadas verbais acabam mesmo por converter o bem-humorado Garcia de Resende num ser muito apropriado para aparecer como momo nos serões da Corte, quer dizer, como ator mascarado ao serviço de um espetáculo áulico de natureza (pré)teatral. É isso o que expõe explicita e pormenorizadamente Afonso Valente (IV, núm. 879), desenhando uma cena cómico-burlesca e histriónica nos seguintes termos:
Pareceis ü pouco o farto
pregador da vida eterna, grega bebada de parto
antre cubas em taverna.
Bentas sejam de Balam
as fadas que vos fadaram, as tetas que vos criaram, qu'assi vos empetrinaram para momo no seram $^{39}$.

Tal como a Momo, na qualidade de estereótipo burlesco no âmbito dos mitos gregos, a figura de Garcia de Resende liga-se ao cortejo de Baco, não só por essas abundantes alusões ao vinho, mas também explicitamente pela comparação que João Rodriguez de Sá (IV, núm. 864) estabelece entre ele e um instrumento de percussão próximo ao tambor, de forma arredondada e de origem africana, o qual designa como atabaque de Baco -vê-se bem, portanto, como a inversão e transgressão simbólica afeta o par antinómico erudito/popular, que é desconstruído e reconstruído por um riso que se sobrepõe à lógica ${ }^{40}$.

\footnotetext{
${ }^{38}$ Claudiana SoEREnSen, "A carnavalização e o riso segundo Mikhail Bakhtin", Travessias [revista electrónica], 5, 1 (2011), disponível em <http://e-revista.unioeste.br/index.php/travessias/article/ view/4370/3889> [Consulta 13/09/2019].

39 O itálico é nosso.

${ }^{40}$ Lembre-se que uma ilustração da sobrevivência da junção Momo-Baco em textos literários posteriores aparece recolhida já na nota 9 do presente estudo.
} 
Assim, fluem os nomes próprios tirados do âmbito erudito, dos quais não se aproveitam os valores ligados a um status de prestígio, mas procura-se a sua associação com a superabundância e corpulência: o citado introdutor do humanismo em Portugal põe o compilador não só em relação com Baco, mas também com outro mito da cultura grega, o gigante semi-humano Caco (IV, núm. 864); e, por sua vez, Afonso de Valente lança mão do bíblico Balaão (IV, núm. 879) não pelo seu significado, mas pelo significante de tal antropónimo, que sugere a ideia de aumento. Tudo se enche de fantasia num maremagnum em que tetas e fadas se abençoam conjuntamente como criadores do momo para o serão. E, ainda, a cenificação da mogiganga se completa parodicamente com a companhia de uma "dama-saca" de algodão e os efeitos da simples luz de um tição, um pedaço de lenha acesa: Onde todos bem veram / vossa groria, vossa fama, / caber-vos-á por dama / üa saca d'algodam / por tocha ü gram tiçam (IV, núm. 879).

Por outro lado, a focagem do corpo faz-se sob um prisma de hipertrofia que conduz também à animalização. Com efeito, um grupo importante de termos de comparação são extraídos do campo semântico de animais caraterizados pelo seu excesso anatómico, sobretudo o urso, o touro ou a vaca e o porco -todos eles com dimensões simbólicas muito marcadas no ocidente europeu e máscaras utilizadas em figurações carnavalescas. Por exemplo, Afonso Valente aponta para a semelhança do corpo de Garcia de Resende com um usso empalado, quer dizer, submetido a um antigo suplício que consistia em espetá-lo pelo ânus, deixando-o assim até morrer (vol. IV, núm. 879). Quanto a João Rodrigues de Sá recorre à imagem de um touro cevado em lameiro (IV, núm. 864), no sentido de gordo e saciado em prado com abundante pastagem, que nos traz à memória as tetas, que semelham cevadeiras, isto é, os sacos que se suspendem ao pescoço dos animais da espécie vacum para comerem, aplicada precisamente pelo nosso jogral Joan Baveca (B 1458, V 1068) às glândulas mamárias de uma mulher. Aliás, do porco provém o paio, enchido de carne ensacada em tripa mais grossa do que o chouriço, que este último poeta cita também como elemento análogo ao corpo em questão: paio mui recheado, / dependurado em fumeiro (IV, núm. 864) ${ }^{41}$.

\footnotetext{
${ }^{41}$ Com respeito à conexão entre carnaval e os apetites do corpo, como a gula, que se manifesta sem restrições e com a presença de alimentos singulares desta época e elaborados com porco -alguns recebem mesmo um nome próprio, como pedropérez, ou designam-se como bandullo: "En Cotobad, en Galicia, junto a otros elementos harinosos, era propio del Carnaval la bincha o bandullo, un budín hecho en la vejiga del cerdo (...)". Por otro lado, la voracidad, y la gordura como su resultado, han sido, también, consideradas como conducta o estado emblemático del Carnaval. En Galicia todavia se dice de una persona muy gorda que está como un antroido, vale decir que está como un Carnaval" (cf. Manuel GutiérRez Estévez, "Una visión antropológica del carnaval", em Javier Huerta Calvo (ed.), Formas carnavalescas en el arte y la literatura, Barcelona, Serbal, 1989, pág. 43). Para algumas alusões à carne de porco no processo de carnavalização de Garcia de Resende, consulte-se José CAMõEs, Poesia de Garcia de Resende, Lisboa, Comissão Nacional para as Comemorações dos Descobrimentos Portugueses, 1999, pág. 92.
} 
A PROPÓSITO DE MOMO E CORPO CARNAVALESCO:

Por outro lado, não podemos deixar de assinalar outras analogias ao serviço do retrato carnavalesco que se inspiram em fenómenos ou elementos da natureza a fim de sublinhar flacidez, carnosidade e vultuosidade. Entre bastantes outras destaca-se, pelo seu perfil quase surrealista, a que Afonso de Valente (IV, núm. 879) estabelece entre as nádegas do bem-humorado eborense e as lezírias ou terrenos alagadiços à beira do Tejo, assim como entre as suas costas sem saliências ósseas e os do próprio monte. Eis os versos em que se unem comparativamente traseiro e paisagem para criar a imagem de extensão do traseiro:
Gram lavoira se vos perde, porque vai em tal ensejo vosso cu de verde a verde como o Tejo.
Is cobrindo toda a ponte, as leziras nom desfaço, os lombos de monte a monte sem parecer espinhaço.

O segundo traço relativo à caricatura de Garcia de Resende que o faz tão apropriado para momo no serão alicerça-se na troça das suas capacidades artísticas, tal como acontece no espaço galego-português com o referido jogral Saco que retrata Tamalancos e a que fizemos referência em páginas anteriores. No caso do compilador, poeta e músico do Cancioneiro Geral, estas rebaixam-se por meio da sua conversão em incontinências gasosas através de jogos semânticos, mostrando um plano da dimensão carnavalesca que ultrapassa a perceção visual e se desloca a outros sentidos: ouvido e olfacto. No tocante à produção de ruídos destacam-se, de facto, expressões como charamelam alporcado (vol. IV, núm. 864), a qual utiliza João Rodrigues de Sá com fins descritivos, tendo em conta que a charamela se corresponde com um instrumento de sopro de timbre estridente e alporca é o nome dado vulgarmente à doença da tuberculose, manifestada, entre outros sintomas, através da mudança de voz e/ou afonia.

Com o duplo sentido de desafinado tangedor e indíviduo flatulento também se devem interpretar as identificações humorísticas com outros artefatos de sopro que propõe Afonso de Valente (vol. IV, núm. 879), tais como a sacabuxa, tipo de trombeta do século XV e origem do moderno trombone. Aliás, afirma o poeta zombeteiro que Garcia de Resende tem sido visto na feira da cidade flamenga de Anvers (atual Antuérpia) a tocar mui grandes trombas ${ }^{42}$ e associa-o a um produ-

\footnotetext{
${ }^{42}$ Sublinhe-se que os termos charamela, trombeta e sacabuxa, tanto podem designar o instrumento específico como o instrumentista que o toca ou, ainda, o instrumento genérico de sopro. Nem é preciso
} 
tor de vento através de denominações intensivas e amalgamentos do tipo tres mil odres de vento, em que todas as propriedades comentadas e modos de representação parecem unir-se: gordura por formato arredondado do recipiente, flacidez pela contenção de líquido, gosto pelo vinho pelo tipo de substância guardada e flatulência pelo vento. De modo mais explicitamente escatológico, equipara-o a uma bufa, evocada com certos pormenores: bufa calada / do Levante no Verão, quer dizer, expelida em silêncio e semelhante ao ar estival procedente do Leste, elemento meteorológico cuja intensidade pode ser muito alta.

Tal como acontece no Cancioneiro Geral, a presença da ventosidade ligada a um agente de espetáculo poético-musical também se encontra presente como motivo de humor na nossa tradição satírica galego-portuguesa. Salvando as distâncias, cabe trazer aqui a colação a tenção bilingue em que D. Arnaldo (porventura o trovador provençal Arnaut Catalan) solicita ao rei Afonso X que o faça almirante (B 477). Em compensação, oferece os seus dotes gasosos, que constituirão um eficaz recurso para afundar os navios inimigos. O monarca dispõe-se então a nomeá-lo Almirante Sison -nome que implica a animalização do alvejado, pois remete para a ave cujo macho emite um som curto e seco nos saltos- , ele agradece o título e assegura que também expelirá ventos suaves, capazes de agradar a sua senhor, o que provoca a advertência do seu interlocutor: que non é bon doneador / quen esto fezer a ciente (B 477). Tenha-se em conta que o trovador provençal acima referido tinha composto, alguns anos antes, uma tenção à volta do mesmo tema com Raimon Berenguer IV, Conde de Provença, a qual reproduz precisamente o esquema da canso que leva por incipit Quan vei la lauzeta mover, de Bernart de Ventadorn - assim sendo, estaríamos perante uma citação paródica do nome "Ventador"? ${ }^{43}$.

$\mathrm{Na}$ verdade, resulta possível descobrir a convergência dessas manifestações grotescas e certas conceções científicas da Antiguidade e Idade Média que li-

\footnotetext{
lembrar que a presença da música foi constante em todos os momentos de lazer nas cortes europeias da época, o que fica bem testemunhado na iconografia e nas alusões das crónicas ao uso de estridentes fontes sonoras (trombetas, atabales, sacabuxas, charamelas, cornetas, atambores etc.). Aliás, no Cancioneiro Geral, acumulam-se termos relativos a notas, signos e diversas propriedades relativas à teoria da música: bemoles, retrapoles, gama ut o bequadrado, de cujo significado literal e contextual nos informa com precisão Manuel Pedro FERREIRA, esclarecendo que "o facto de a música de Resende nos ser apresentada a não caber na escala, tem o efeito retórico de amplificar a ideia de excesso que no poema vem associado à flácida redondez do personagem" em "L’homme armé no Cancioneiro de Resende", Revista da Faculdade de Ciências Sociais e Humanas, 16 (2005), págs. 259-268.

${ }^{43}$ É claro que o motivo do "pet” conta com longínquos antecedentes literários, da tradição clássica, passando pelos fabliaux e o trovadorismo ocitano, no qual se destaca, para além dessas duas composições dialogais que partilham um mesmo trovador, uma cobla em que aparece uma "rainha de ventosidades" (dels pez soberana), tal como explica Esther CoRRAL DíAz, "O vituperium feminino: a cualificación da peideira nas cantigas de escarnio”, em José Carlos Ribeiro Miranda (org.), En Doiro antr'o Porto e Gaia. Estudos de Literatura Medieval Ibérica, Porto, Estrategias Criativas, 2017, págs. 367-379.
} 
A PROPÓSITO DE MOMO E CORPO CARNAVALESCO:

gam a flatulência com questões de sexualidade a partir da medicina hipocrática, a qual vigorou como paradigma durante séculos, deixando evidentes vestigios na cultura popular. Com efeito, o célebre tratado De flatibus, composto por um autor desconhecido do século $\mathrm{V}$ e destinado a um público não especialista, foi objeto de inúmeras interpretações. Concede-se ali uma importância fundamental ao flato na sua qualidade de agente causal do mundo, partindo de que o corpo dos homens é alimentado por víveres, bebidas e sopro e concluindo que estes poderiam mesmo viver vários dias privados dos dois primeiros elementos, mas pereceriam se obstruíssem as vias do terceiro durante um breve tempo. Embora o anónimo autor reconheça que as doenças não apresentem semelhanças entre si, devido à diversidade dos espaços, afirma que a origem de todas elas está no ar, vendo na excreção o remédio, pois a arte da medicina reside sempre, conforme as suas teorias, em dar o que falta ou tirar o que sobeja ${ }^{44}$. Aliás, considerando-se a ereção e a ejaculação como o resultado natural da inchação das cavernosidades e da pressão do ar, respetivamente, prescreviam-se os alimentos que provocam ventosidades para o aumento da potência sexual masculina -e, na verdade, a ligação coito/ventosidade não chega a resultar rara na manifestação do prazer sexual no cosmos medieval ${ }^{45}$.

\section{CONCLUSÕES: CORPO E GESTO PARA O ESBOÇO DE UMA ANTROPOLOGIA} DO HUMOR E DO RISO

Enfim, são muitos os elementos lexicais que nos situam perante uma sátira resultante da justaposição entre obscenidade e sexualidade a partir de eufemismos e disfemismos ao longo de toda a Idade Média e de uma perceção carnavalesca que se projeta nos textos galego-portugueses e nos recolhidos no Cancioneiro Geral sobre os mesmos temas, embora com algumas maiores ou menores particularidades derivadas dos seus correspondentes contextos. Nem é preciso sublinhar que uma das questões centrais que se tem de enfatizar nos estudos sobre humor e riso é a sua contemporaneidade, quer dizer, cada período se ri de elementos diferentes e o faz de maneiras também distintas. O que aos nossos antepassados lhes produzia riso, "a nosotros, por el mencionado proceso de civili-

\footnotetext{
44 Veja-se o artigo de Mercedes LóPez SALVÁ, "Medicina y pensamiento en el corpus hippocraticum”, Myrtia. Revista de filologia clásica, 6 (1991), págs. 28-29.

${ }^{45}$ No estudo acima citado de CoRral DíAz (“O vituperium feminino...”, pág 375) contabilizam-se, de facto, até dez cantigas em que a presença de peer se torna alvo de mofa num clima de obscenidade. Nesse sentido, cumpre trazer a colação, por exemplo, o texto em que Joan Soarez Coelho revela a Luzia Sanchez que, pelo seu excesso de atividade e o padecimento de doenças venéreas, não poderá satisfazê-la, exprimindo-se nos seguintes termos: pois eu foder non posso, peer-vos-ia (V 1017); ou o que Afons'Eanes de Coton dirige a uma alcoviteira, atribuindo-lhe a tripla adjetivação de velha, fududancua e peideira (B 1587, V 1119).
} 
zación, nos parece de una crueldad absurda y de mal gusto, que nos provoca más bien un sentimiento de desagrado y repugnancia ante lo que estamos leyendo" ${ }^{46}$.

$\mathrm{O}$ investigador Giuseppe Tavani ${ }^{47}$, algumas décadas atrás, tem-se aproximado do cómico e carnavalesco nas cantigas de escárnio e maldizer como o produto de uma manifestação cultural criada sob o signo da liberdade e a alteração ou inversão da ordem, mas até agora ninguém se deteve pormenorizadamente na compilação de Quatrocentos sob o mesmo prisma, o que resulta surpreendente, dado o aproveitamento de uma exploração nesse sentido, no seguimento de uma linha que entronca com a tradição. E chama também a atenção que não se insista com maior ênfase sobre a palavra momo e a expressão narizes no momo, utilizadas num discurso escarninho em que o jogral galego Joan Baveca (B 1457, V 1067) invoca o seu conterrâneo Pero d'Ambroa, pois refletem-se aí todas as marcas dominantes, via de regra, na conceção do corpo carnavalesco. $\mathrm{O}$ facto de não encontrarmos recolhido o termo em repertórios lexicográficos com o significado de parte posterior e inferior do corpo humano suscita perguntas sobre a sua origem e a necessidade estabelecer um diálogo entre as diferentes hipóteses. Tendo em conta o uso dessa forma no âmbito da representação mímico-gestual, cabe falar de homonímia?, de polissemia?

Pela primeira vez, levou-se a cabo o confronto da cantiga de escárnio e maldizer em questão com documentação do século XIII e doutros momentos posteriores em que o facto de "momear" ganha cada vez maiores dimensões, assim como com os textos da recolha portuguesa de Garcia de Resende que aludem às cenificações festivas e à carnavalização do corpo nos serões cortesãos. $\mathrm{Na}$ verdade, a focagem de momo implicou, inevitavelmente, não só considerações relativas à esfera léxico-semântico do galego-português e doutras línguas, mas o aprofundamento em aspectos de cariz antropológico e da história das mentalidades no Ocidente peninsular ao longo da Idade Média. Por um lado, descobrimos as isotopias derivadas da junção de riso e corpo (quer com as suas formas salientes e entrantes quer com excreções); por outro, vislumbramos marcas de uma (pré)teatralidade a partir de máscaras que se espelham em versos, transformando identidades segundo os códigos dos diversos contextos sociais e lúdicos.

\footnotetext{
${ }^{46}$ Victoriano LóPEZ RonCERo, De bufones y picaros: la risa en la novela picaresca, Madrid/Frankfurt am Main, Iberoamericana / Vervuert, 2010, pág. 58.

47 "O cómico e o carnavalesco nas cantigas de escarnho e maldizer", Boletim de Filologia. Homenagem ao Professor Rodrigues Lapa, 29 (1984), págs. 59-74.
} 
A PROPÓSITO DE MOMO E CORPO CARNAVALESCO:

DE JOAN BAVECA E A SÁTIRA GALEGO-PORTUGUESA AO CANCIONEIRO GERAL

\section{BIBLIOGRAFIA}

Alberti, Verena, "O riso, as paixões e as faculdades da alma", Textos de História, 3, 1 (1995), págs. $5-25$

Alvar, Carlos "Las poesías de Pero Garcia d'Ambroa", Studi Mediolatini e Volgari, 32 (1986), págs. 5-112

Álvarez Pelliteiro, Ana María, “Aproximaciones al estudio del teatro medieval en España”, El Crotalón, 2 (1985), págs. 13-35.

Arias Freixedo, Xosé Bieito, Per arte de foder. Cantigas de escárnio de temática sexual, Berlin, Frank \& Time, 2017.

Asensio, Eugenio, "De los momos cortesanos a los autos caballerescos de Gil Vicente", en Estudios Portugueses, Paris, Fundação Calouste Gulbenkian, 1974, págs. 25-36.

Bakhtin, Mikhail, A cultura popular na Idade Média e no Renascimento: o contexto de François Rabelais, São Paulo, Hucitec / Brasília, Editora da UnB, 2000.

Bernardes, José Augusto Cardoso, Sátira e lirismo. Modelos de síntese no teatro de Gil Vicente, Coimbra, Universidade de Coimbra, 1996, págs. 66-90.

Bluteau, Raphael, Vocabulario Portuguez e Latino, vol. 5, Lisboa, Oficina de Pascoal da Sylva, 1716.

Botta, Patricia, "Las rúbricas en el Cancioneiro Geral de Resende II", em Mercedes Pampín Barral e Carmen Parrilla García (coords.), Actas del IX Congreso Internacional de Asociación Hispânica de Literatura Medieval, vol. I, A Coruña, AHLM, 2005, págs. 489505.

Brasil, Reis (ed.), Crónica da Tomada de Ceuta, Lisboa, Europa-América, 1992.

Callón, Carlos, As relacións sexoafectivas intermasculinas e interfemininas no trobadorismo galego, tese de doutoramento, Universidade da Coruña, 2017.

Camões, José, Poesia de Garcia de Resende, Lisboa, Comissão Nacional para as Comemorações dos Descobrimentos Portugueses, 1999.

Corominas, Joan, e Pascual, José Antonio, Diccionario Crítico Etimológico Castellano e Hispánico, Gredos, Madrid, 1981.

Corral Díaz, Esther, "O vituperium feminino: a cualificación da peideira nas cantigas de escarnio", em José Carlos Riberio Miranda (org.), En Doiro antr'o Porto e Gaia. Estudos de Literatura Medieval Ibérica, Porto, Estrategias Criativas, 2017, págs. 367-379.

Dias, Aida Fernanda (ed.), Cancioneiro Geral de Garcia de Resende, Maia, Imprensa Nacional-Casa da Moeda, 1998, 4 vols.

Ferreira, Manuel Pedro, "L'homme armé no Cancioneiro de Resende", Revista da Faculdade de Ciências Sociais e Humanas, 16 (2005), págs. 259-268.

Ferreiro, Manuel; Martínez Pereiro, Carlos Paulo; Tato Fontaiña, Laura, Normas de edición para a poesia trovadoresca galego-portuguesa medieval. Guidelines for the Edition of Medieval Galician-Portuguese Troubadour Poetry, A Coruña, Servizo de Publicacións, 2007.

Gutiérrez Estévez, Manuel, “Una visión antropológica del carnaval”, em Javier Huerta Calvo (ed.), Formas carnavalescas en el arte y la literatura, Barcelona, Serbal, 1989, págs. 33-62. 
Jordá Fabra, Tatiana, Hacia el actor profesional en el teatro peninsular del Renacimiento, tese de doutoramento, Universitat de Valência, 2015.

Keil, Johann Georg (ed.), Las comedias de d. Pedro Calderón de la Barca, t. 3, Leipzig, Brockhaus, 1829.

Lopes, Graça Viceira (coord.), Cantigas medievais galego-portuguesas [base de dados online], Lisboa, Instituto de Estudos Medievais, FCSH/NOVA, 2011, disponível em $<$ https://cantigas.fcsh.unl.pt/apresentacao.asp $>$ [Consulta 22/12/2019].

López Roncero, Victoriano, De bufones y pícaros: la risa en la novela picaresca, Madrid/ Frankfurt am Main, Iberoamericana / Vervuert, 2010, págs. 57-58.

López Salvá, Mercedes, "Medicina y pensamiento en el corpus hippocraticum”, Myrtia. Revista de filologia clásica, 6 (1991), págs. 29-48.

Lorenzo Gradín, Pilar, "Modelos épicos y artúricos en la lírica gallego-portuguesa”, em Marco Piccat e Laura Ramello (coords.), Epica e cavalleria nel Medioevo, Atti del Seminario internazionale, Alessandria, Edizioni dell'Orso, 2011.

Lorenzo Gradín, Pilar, “Teatralidad y teatro medievales en el occidente peninsular”, Revista de lenguas y literaturas catalana, gallega y vasca, 4 (1994-1995), págs. 87-105.

Maleval, Maria do Amparo Tavares, O teatro medieval e seus congêneres em Santiago de Compostela (séculos XII-XIII), Niterói, Eduff [no prelo].

Manrique Frias, Gerardo, Los mitos clásicos en los dramas mitológicos de Calderón de la Barca. Estudio de sus referencias básicas: personajes y lugares, tese de doutoramento, Universidad Nacional de Educación a Distancia, Madrid, 2010.

Marcenaro, Simone, L'equivocatio nella lirica galego-portoghese medievale, Alessandria, Edizioni dell'Orso, 2010.

Marques, José, “Os Santos dos Caminhos Portugueses”, Revista da Faculdade de Letras, 7, 1 (2006), págs. 243-262.

Martínez Pereiro, Carlos Paulo, A indócil liberdade de nomear. Por volta da interpretatio nominis na literatura trovadoresca, A Coruña, Espiral Maior, 1999.

Mazo Karras, Ruth, e Murray, Jacqueline, “The Sexual Body”, em Linda Kalof(ed.), A Cultural History of the Human Body in the Medieval Age (500-1500), London, Bloomsbury, 2010, págs. 59-75.

Meyer-Lubke, Wilhelm, Romanisches etymologisches Wörterbuch, Heidelberg, Carl Winter's Universitätsbuchhandlung, 1935.

Morán Cabanas, Maria Isabel, Traje, gentileza e poesia. O campo semântico do moda e da vestimenta no Cancioneiro Geral, Lisboa, Estampa, 2002.

Morán Cabanas, Maria Isabel, Festa, teatralidade e escrita. Esboços teatrais no Cancioneiro Geral de Garcia de Resende, A Coruña, Biblioteca Arquivo Teatral Francisco PilladoMayor; Universidade da Coruña, 2003. 
A PROPÓSITO DE MOMO E CORPO CARNAVALESCO:

Morán Cabanas, Maria Isabel, "Riso e traje, uma combinação recorrente no Cancioneiro Geral", em Elisa Nunes Esteves, Isabel Barros e Margarida Reffóis (coords.), O riso: teorizações, leituras, realizações, Lisboa, Caleidoscópio, 2015, págs 147-165.

Nodar Manso, Francisco, Teatro menor galaico-portugués (siglo XIII), Reichenberger, Kassel, 1990.

Oliveira, António Resende de, Depois do espectáculo trovadoresco. A estrutura dos cancioneiros peninsulares e as recolhas dos séculos XIII e XIV, Lisboa, Colibri, 1994.

Osório, Jerónimo, Da vida e feitos d'el-rei D. Manuel I, Porto, Livraria Civilização, 1944

Otero Piñeyro Maseda, Pablo S., e Garcia-Fernández, Miguel, "Los testamentos como fuente para la historia social de la nobleza. Un ejemplo metodológico: tres mandas de los Valladares del siglo XV", Cuadernos de Estudios Gallegos, vol. 60, núm. 126 (2013), págs. 125-169.

Paz, Octavio, Conjunciones y disjunciones, Barcelona, Seix-Barral, 1991.

Ramos, Maria Ana, "Invoco el rrey Dom Denis... Pedro Homem e o Cancioneiro da Ajuda", em Santiago Fortuño Llorénse e Tomàs Martínez Romero (eds.), Actas del VII Congrès de la Asociacion Hispanica de Literatura Medieval, vol. I, Castelló de la Plana, Universitat Jaume I, 1999, págs. 127-179.

Rivas, Aitor, "O que veer quiser, ai cavaleiro, / Maria Pérez, leve. Algum dinheiro: amor, dinero y género en las cantigas gallego-portuguesas", em Inga Baumann e Slaven Waelti (eds.), Vom Liebespfand zur Singlebörse Über die ökonomische Rhetorik der Liebe, Berlin, Lit Verlag, 2019, págs. 59-87.

Rodrigues Lapa, Manuel (ed.), Cantigas d'escarnho e de mal dizer, Vigo, Galaxia, 1965.

Rodríguez, José Luís, “A mulher nos cancioneiros. Notas para um anti-retrato descortês", en Aurora Marco López (coord.), Simpósio Internacional Muller e Cultura, Santiago de Compostela, Universidade, 1993, págs. 43-67.

Soerensen, Claudiana, "A carnavalização e o riso segundo Mikhail Bakhtin”, Travessias [revista electrónica], 5, 1 (2011), disponível em <http://e-revista.unioeste.br/index.php/ travessias/article/view/4370/3889> [Consulta 13/09/2019].

Sousa, António Caetano de, Provas da história genealógica da casa real portuguesa, vol. 1 [s. 1.], Oficina Silviana da Academia Real, 1739, págs. 32-33.

Souto Cabo, José António, "Pedro Garcia de Ambroa e Pedro de Ambroa", Revista de Literatura Medieval, 18 (2006), págs. 225-248.

Tavani, Giuseppe, "O cómico e o carnavalesco nas cantigas de escarnho e maldizer", Boletim de Filologia. Homenagem ao Professor Rodrigues Lapa, 29 (1984), págs. 59-74.

Tocco, Valeria, Poesias e sentenças de D. Francisco de Portugal - $1^{\circ}$ Conde de Vimioso, Lisboa, Comissão Nacional para as Comemorações dos Descobrimentos Portugueses, Lisboa, 1999.

Vieira, Yara Frateschi, "Retrato medieval da mulher: a bailarina com pés de porco", Estudos Portugueses e Africanos, 1 (1983), págs. 95-110. 
Vieira, Yara Frateschi, En cas dona Maior. Os trovadores e a corte señorial galega no século XIII, Laiovento, Santiago, 1999.

Víñez Sánchez, Antonia, El trovador Gonçal'Eanes Dovinhal. Estudio histórico y edición, Santiago de Compostela, Universidade de Santiago de Compostela, 2004 (Anexo de Verba, Anuario Galego de Filoloxía, 55).

Welsford, Enid, The Court Masque: a study in the relationship between poetry and the revels. Cambridge, University Press, 1927.

Zilli, Carmelo (ed.), Johan Baveca. Poesie, Bari, Adriatica Editrice, 1977. 